\title{
ULTRASTRUCTURAL CHANGES OF THYROTROPIC CELLS IN THE DYNAMICS OF EXPERIMENTAL IMMUNOSTIMULATION
}

Inessa Bobrysheva, Svetlana Kashchenko, Lugansk State Medical University, inessa_lug@mail.ru

The endocrine and immune systems are interrelated via a bidirectional network. Thyroid-stimulating hormone plays a critical role as an endogenous mediator of immune activity.

Purpose of study was to determine the dynamics of changes of thyrotropic cells ultrastructure in modeling immunostimulation in mature male rats by subcutaneous injection of imunofan in a dosage $0,7 \mathrm{mg} / \mathrm{kg}$ of body weight. The pituitary samples were taken on $1^{\text {st }}, 7^{\text {th }}, 15^{\text {th }}, 30^{\text {th }}$ and $60^{\text {th }}$ day after treatment and then fixed in glutaraldehyde for electron microscope.

The study showed the increase of functional activity of the thyrotropic cells. The significant increase of areas of the cells and their nuclei, area of mitochondria and secretory granules was established since 7th day after imunofan treatment.

UDC Numbers: 577.3, 615.275, DOI: 10.12955/cbup.2013.47

Keywords: experimental immunostimulation, thyrotropic cells, electron microscopy

\section{Introduction}

The endocrine and immune systems are interrelated via a bidirectional network in which hormones affect immune function and, in turn, immune responses are reflected in neuroendocrine changes (Gaillard, 2001; Gaillard, 2003; Jara, 2006; Granado, 2011). Interactions of immune and endocrine systems occur at many stages of embryonic and neonatal development, and they are a continual part of normal homeostatic balance (Weigent, 1990; Weigent, 1995). There is communication between these two systems via cytokines, neurotransmitters and peptide hormones which act through the same receptor molecules (Markovich, 2004). The cells of the immune system have receptors to hormones of anterior pituitary, including thyroid-stimulating hormone (Coutelier, 1990). The hormones of pituitary gland are the group of substances of peptide nature, extraordinarily heterogeneous on biological properties (Sepiashvilli, 2003; Tirtishnaya, 2007). Many investigators have reported that hormones of pituitary gland are able to change activity of metabolism and function of different cells, including the cells of the immune system, influencing not only through the hormones of corresponding peripheral endocrine glands but also directly on these cells (Karl, 2003; Ribakina, 2005; Tirtishnaya, 2007).

Thyroid-stimulating (thyrotropic) hormone, a glycoprotein hormone produced by the anterior pituitary and released into the blood upon induction by hypothalamic-derived thyrotropin-releasing hormone (TRH). As Armstrong (2001) write, thyroid-stimulating hormone plays a critical role at two levels, the first being as an endogenous mediator of immune activity, the second being as a molecular signal used by the immune system to communicate with the thyroid. Release of thyroid-stimulating hormone from cytoplasmic endosomes of thyrotropic cells then would be available for use by antigen-presenting 
cells, $\mathrm{T}$ cells and $\mathrm{B}$ cells, thereby enhancing cytokine synthesis, $\mathrm{T}$ cell activity and antibody responses from B cells. A role for thyroid-stimulating hormone in antibody synthesis by B cells has been demonstrated in several laboratories (Kruger, 1989; Harbour, 1990).

Researches, conducted the last years in many countries of the world, have allowed to develop and introduce in clinical practice new complex approaches in treatment and prophylaxis of different nosologic forms of diseases with the use of immunotropic preparations of the directed action. Imunofan is the representative of the IV generation of derivates of thymic hormones, created by nanotechnology (Lebedev, 1999).

However, among plenty of information we did not find the sufficient level of disclosure of problem of structure of pituitary gland after application of modern immunotropic preparations of new generation, created with the use of nanotechnology.

The purpose of our study is to identify features of ultrastructural changes of thyrotropic cells of pituitary glands in the dynamics of experimental immunomodulation.

\section{Materials and methods}

We used the model of immunostimulation in 50 mature male rats by subcutaneous injection of imunofan. All animals were divided into two groups:

- control group 25 rats which received $0,9 \%$ soluble sodium chloride,

- main group 25 rats with experimental model of immunostimulation.

Imunofan was injected on 1,3, 5, 7, 9 days throughout the experiment. The experimental animals were sacrificed under Rausch-anesthesia on $1^{\text {st }}, 7^{\text {th }}, 15^{\text {th }}, 30^{\text {th }}$ and $60^{\text {th }}$ day after treatment, according to the rules outlined by the European Convention for the Protection of Vertebral Animals (Strasbourg, 1986). The brain along with the pituitary was immediately out. Pituitary glands were measured and weighed. For Electron Microscope the pituitary glands were fixed in fresh ice cold 3\% glutaraldehyde for three hours and then four hours in $0.1 \mathrm{M}$ cacodylate - buffered. The tissues were washed in buffer and then post fixed for one to two hours in $1 \% 0.067 \mathrm{M}$ cacodylate- buffered osmium tetroxide. After dehydration with graded series of alcohol, the tissues were cleared in propylene oxide solution and embedded in araldite resin which would be polymerized at $60^{\circ} \mathrm{C}$. Then, ultrathin sections from selected blocks were cut glass knife and picked up on 400-mesh copper gride. Thin sections were examined under EM-125 electron microscope. We determined the area of the cells and their nuclei, area of the mitochondriaans secretory granules. The data obtained were processed by using computer program Statistix 6.0. The significant difference was established at $\mathrm{p}<0.01$.

\section{Results and discussion}

In laboratory rats the pituitary gland is dorso-ventrally compressed. The gland has two functional components - adenohypophysis and neurohypophysis. Adenohypophysis consists of three derivatives of Rathke's pouch: pars tuberalis, pars intermedia and pars distalis. The pars distalis of adenohypophysis is separated from the neurohypophysis by residual lumen while the pars intermedia are in close contact with the posterior pituitary. The cells of the adenohypophysis are organized in endocrine cell clusters and cords separated by the sinusoidal capillaries of relatively large diameter. At the level of the light microscope, distinguish three types of cells according to their staining reactions, namely, basophilic cells (near 10\%), acidophilic cells (40\%) and chromophobe cells (50\%). Classification of the cellular types is based on the shape and size of the cells and staining properties of 
the cytoplasmic granules. The criterion of identification and differentiation of endocrine cells of adenohypophysis at the ultrastructural level is their shape, size, structural features and distribution of secretory granules in the cytoplasm. The current concept of the estimation of the level of cellular activity is based on the morphology of the nucleus, condition of the Golgi apparatus, structure of the mitochondria, rough endoplasmic reticulum, the shape, size and elaboration of the secretary granules, liberation of these granules from the cell.

Thyrotropic cells are the largest cells of pars distalis of adenohypophysis, are small in number, found singly, and located diffusely in parenchyma of the gland near blood capillaries. These cells are generally elongated or polyhedral in shape. The nucleus is large with chromatin granules, situated in the central part of the cells or eccentrical in position, contains one or two nucleoli. Golgi apparatus is not well developed; consists of flattened sacs and small vesicles. Mitochondria are round, but sometimes long rod like. The rough endoplasmic reticulum develops poorly and appears as parallel lamellae or the dilated cisterns. Cisterns of rough endoplasmic reticulum present arranged parallel to one another and are distributed throughout the cytoplasm. Secretary granules are spherical and very small in size about $80-150 \mathrm{~nm}$, and of moderate electron density, small in numbers, mainly located along a cytolemma. The granules are the smallest among those found in all glandular cells. The secretory granules at the beginning of formation are often observed near Golgi apparatus.

Ultramicroscopic and morphometric research of pars distalis of adenohypophysis of mature male rats in 1 day after imunofan treatment showed that gland cytoarchitectonics does not change and practically does not differ from such in the control group of animals (Table 1).

Table 1: Morphometric indices of thyrotropic cell of pars distalis of adenohypophysis of mature male rats of control group and after imunofan treatment

\begin{tabular}{|c|c|c|c|c|c|}
\hline $\begin{array}{c}\text { Experimental } \\
\text { groups } \\
\text { Control }\end{array}$ & $\begin{array}{c}\text { Terms } \\
\text { (in days) }\end{array}$ & $\begin{array}{c}\text { Area } \\
\text { of cell }\left(\mu \mathrm{m}^{2}\right)\end{array}$ & $\begin{array}{c}\text { Area } \\
\text { of nucleus } \\
\left(\mu \mathrm{m}^{2}\right)\end{array}$ & $\begin{array}{c}\text { Area of } \\
\text { mitochondria } \\
\left(\mu \mathrm{m}^{2}\right)\end{array}$ & $\begin{array}{c}\text { Area of } \\
\text { secretory } \\
\text { granules }\left(\mu \mathrm{m}^{2}\right)\end{array}$ \\
\cline { 2 - 6 } & 1 & $115.27 \pm 6.24$ & $34.38 \pm 1.40$ & $12.97 \pm 0.87$ & $7.44 \pm 0.47$ \\
\cline { 2 - 6 } & 15 & $117.45 \pm 5.98$ & $35.66 \pm 1.76$ & $13.67 \pm 0.97$ & $8.35 \pm 0.84$ \\
\cline { 2 - 6 } & 30 & $117.15 \pm 6.31$ & $35.12 \pm 1.65$ & $13.82 \pm 0.71$ & $7.49 \pm 0.38$ \\
\cline { 2 - 7 } & 60 & $118.45 \pm 6.23$ & $35.72 \pm 1.88$ & $15.29 \pm 0.94$ & $8.75 \pm 0.47$ \\
\hline \multirow{3}{*}{$\begin{array}{l}\text { Imunofan } \\
\text { treatment }\end{array}$} & 1 & $116.17 \pm 6.24^{*}$ & $33.98 \pm 1.39$ & $12.44 \pm 0.67$ & $7.25 \pm 0.57$ \\
\cline { 2 - 7 } & 7 & $118.85 \pm 5.42^{*}$ & $37.26 \pm 1.32^{*}$ & $13.60 \pm 0.85^{*}$ & $8.95 \pm 0.89^{*}$ \\
\cline { 2 - 7 } & 15 & $117.65 \pm 5.36^{*}$ & $37.60 \pm 1.65^{*}$ & $14.48 \pm 0.96^{*}$ & $8.43 \pm 0.28^{*}$ \\
\cline { 2 - 7 } & 30 & $116.84 \pm 6.05^{*}$ & $38.63 \pm 1.89^{*}$ & $14.22 \pm 0.78^{*}$ & $7.49 \pm 0.38^{*}$ \\
\cline { 2 - 7 } & 60 & $120.44 \pm 6.23^{*}$ & $37.71 \pm 1.88^{*}$ & $15.77 \pm 0.98^{*}$ & $8.75 \pm 0.47^{*}$ \\
\hline
\end{tabular}

Source: Author; Note: ${ }^{*} \mathrm{P}<0.01$ 
There is significant increase of area of the thyrotropic cells of adenohypophysis in 7 days, while area of the nuclei of cells, and also analogical indices of mitochondria and secretory granules in this term of experiment did not differ significantly from a control value.

Further studies observed tendency to increase of activity of the thyrotropic cells. These cells have large, eccentrically located nuclei, often are near a nuclear membrane that testifies to the active protein synthesis in such cells. There are thyrotropic cells with two nucleoli. Cisterns of rough endoplasmic reticulum are presented by separate fragments. They are dilated in most cases, continue in vacuoles. Secretory granules are placed along cell membrane, forming continuous row. In some areas granules are grouped in 2 rows.

We should note that at animals that were sacrificed on $15^{\text {th }}, 30^{\text {th }}$ and $60^{\text {th }}$ day after imunofan treatment, indices of area of nuclei, mitochondria and secretory granules were significantly increased.

\section{Conclusion}

1. Imunofan treatment caused the expressed change of the ultramicroscopic structure and morphometric indices of the thyrotropic cells of adenohypophysis of mature male rats that testified to their active reaction on exogenous influence.

2. Dynamics of the studied morphological changes, and also morphometric parameters of nuclei and organelles of cells testified to appearance of signs of functional activity of the thyrotropic cells of adenohypophysis: the significant increase of indices of experimental groups in relation to control data was set since the 7 th day after imunofan treatment.

\section{References}

Armstrong, M. D. \& Klein, J. R. (2001). Immune-Endocrine Interactions of the HypothalamusPituitary-Thyroid Axis: Integration, Communication and Homeostasis. Archivum Immunologiae et Therapiae Experimentalis, 49, 231-237.

Coutelier, J., Kehrl, J. H., Bellur, S. S., Kohn, I. D., Notkin, A. L. \& Prabhakar, B. S. (1990). Binding and functional effects of thyroid stimulating hormone on human immune cells. Journal of Clinical Immunology, 10, 204-210. http://dx.doi.org/10.1007/BF00918653 PMid:2170438

Gaillard, R. C. (2001). Interaction between the hypothalamo-pituitary-adrenal axis and the immunological system. Ann Endocrinol (Paris), 62 (2), 155-163.

Gaillard, R. C. (2003). Interactions between the immune and neuroendocrine systems: clinical implications. J Soc Biol, 197 (2), 89-95.

Granado, M., Garc-a-Ceres, C. \& Tuda, M. (2011). Insulin and growth-releasing peptide-6 (GHRP-6) have differential beneficial effects on cell turnover in the pituitary, hypothalamus and cerebellum of streptozotocin (STZ)-induced diabetic rats. Molecular and Cellular Endocrinology, 337 (1-2), 101-103. http://dx.doi.org/10.1016/j.mce.2011.02.002 PMid:21352888

Harbour, D. V., Leon, S., Keating, C. \& Hughes, T. K. (1990). Thyrotropin modulates B cell function through specific bioactive receptors. Prog. Neuroendocrinimmunol, 3, 266-276. 
Jara, L. J., Navarro, C. \& Medina, G. (2006). Immune-neuroendocrine interactions and autoimmune diseases. Clin. Dev. Immunol, 13(2-4), 109-123. http://dx.doi.org/10.1080/17402520600877059 PMid:17162354 PMCid:2270761

Karl, T. \& Weber, A. (2003). Neuroendocrine-Immune Interface. Journal Herz, 28 (8), 692-701. http://dx.doi.org/10.1007/s00059-003-2511-y PMid:14689103

Kruger, T. E., Smith, I. R., Harbour, D. V. \& Blalock, J. E. (1989). Thryrotropin: an endogenous regulator of the in vitro immune response. J. Immunol, 142, 744-747. PMid:2492328

Lebedev, V. V. \& Pokrovsky, V. I. (1999). Imunofan - sinteticheskiy peptidniy preparat novogo pokoleniya [Imunofan - synthetic peptid preparation of new generation]. Vestnik of RAMN, 4, 56-61.

Markovich, L. (2004). Interaction involving the thymus and the hypothalamus-pituitary axis, immunomodulation by hormones. Srpski arhiv za celokupno lekarstvo, 132 (5-6), 187-193. http://dx.doi.org/10.2298/SARH0406187M

Ribakina, E. G. \& Korneva, E. A. (2005). Transduktsiya signala interleukin-1 v protsessakh vzaimodeystviya nervnoy i imunnoy system organizma [Transduction of signal of interleukin-1 in the processes of co-operation of the nervous and immune systems of organism. Vestnik of RAMN, 7, 3-8.

Sepiashvilli, R. I. (2003). Funktsionalnaya sistema immunnogo gomeostaza [Functional system of immune homeostasis]. Allergologia i immunologia, 2, 5-14.

Tirtishnaya, G. V. \& Parahonsky, A. P. (2007). Vzaimosvyaz narusheniy immunnoy i endocrinnoy system pri autoimmunnoy patologii [Intercommunication of disoders of the immune and endocrine systems at autoimmune pathology]. Modern science intensive technologies, 2, 80-81.

Weigent, D. A., Carr, D. J. \& Blalock, J. E. (1990). Bidirectional communication between the neuroendocrine and immune systems. Common hormones and hormone receptors. Ann. N. Y. Acad. Science, 579, 17-27. http://dx.doi.org/10.1111/j.1749-6632.1990.tb48350.x PMid:2186684

Weigent, D. A. \& Blalock, J. E. (1995). Associations between the neuroendocrine and immune systems. J. Leukoc. Biol., 8, 137-150. 